\title{
11
}

\section{RESPONDING TO ALLEGED RUSSIAN INTERFERENCE BY FOCUSSING ON THE VULNERABILITIES THAT MAKE IT POSSIBLE}

\section{Giorgio Comai}

\section{Introduction}

In recent years, the legitimacy of electoral processes in Western democracies has been repeatedly put into question by alleged Russian interference. As abundantly described in journalistic reporting and official investigations, actors associated with Russia have been involved in the production and spreading of disinformation as well as in social media manipulation; moreover, they have waged cyberattacks in the run-up to the US presidential elections of November 2016 (Mueller 2019). Even if the direct impact of Russian efforts has likely been minor, the very fact that meddling was both plausible and possible has been cause for significant concern in Europe and North America. The events associated with Russian meddling have not only highlighted the increased willingness of the Kremlin to use a wide variety of tools in its geopolitical confrontation with the West, but have also served to expose in vivid form newly shaped structural vulnerabilities of contemporary democracies: vulnerability of our information environment to the spread of disinformation and the vulnerability of computer systems of political campaigners to hacking by malicious actors. Widespread calls for policy responses duly ensued (e.g. Cherto and Rasmussen 2019).

This chapter firstly defines 'Russian meddling' as a distinct phenomenon that emerged at the time of the US presidential elections in November 2016 based on a media analysis of mainstream Western media. ${ }^{1}$ It then proceeds by putting the preoccupation with Russian interference in the context of contemporary WestRussia relations and it discusses what is specifically Russian about Russian meddling. Finally, it outlines the work conducted by expert groups and dedicated committees to find policy responses to the vulnerabilities exposed by alleged Russian interference. As will be argued, there is a growing consensus on the structural nature of these vulnerabilities, and an appreciation of the fact that they must be approached without unduly focussing on the Russian component. 


\section{Defining Russian meddling}

The events surrounding the election of Donald Trump to the presidency of the United States in November 2016 generated a significant and unprecedented media hype around 'Russian interference'/'Russian meddling' (the two expressions will be used interchangeably hereafter). The confrontation between Russia and the West has become increasingly apparent since Vladimir Putin first became president of the Russian Federation in 2000, but before 2016 the issue of 'Russian interference' simply did not exist as a consolidated discourse in Western media. As appears from a quantitative analysis of mainstream English-language media such as The New York Times and The Guardian, mentions of Russian meddling' were uncommon before 2016, and almost without exception referred to events in Ukraine and Georgia rather than in established Western democracies. References to 'Russian meddling' became less frequent in The New York Times after the release of the Mueller report in April 2019, while on The Guardian they had a new surge in the run-up to the UK general elections of December 2019 in relation to a new set of scandals. $^{2}$

An analysis of publications on German weekly Der Spiegel and Italian daily $L a$ Repubblica point at similar patterns: references to Russian meddling appear almost exclusively starting in 2016, and mostly in reference to US politics or to domestic scandals associated with the same narrative. ${ }^{3}$ In the full online archive of Der Spiegel, available from the year 2000 , there is a grand total of three articles mentioning Russian interference (russische Einmischung) before 2016, in reference to the 2008 war in Georgia, the 2014 annexation of Crimea, and the war in Syria in 2015; almost all others (about 30) refer to the fallout of events related to the 2016 US presidential elections.

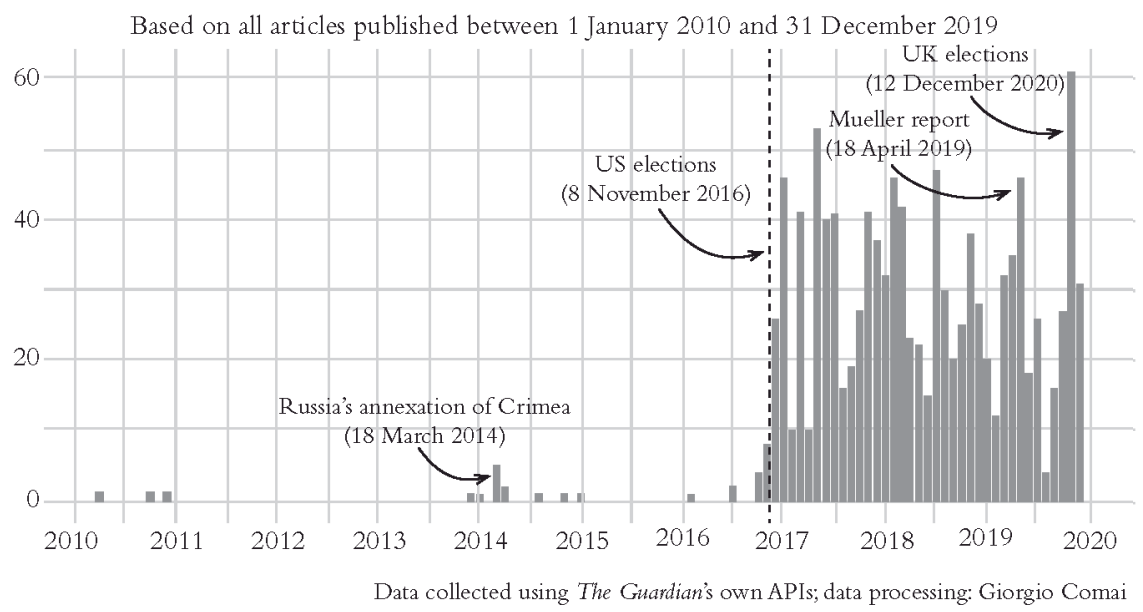

FIGURE 11.1 Articles mentioning 'Russian interference' or 'Russian meddling' in a month in The Guardian 
It is too early to tell if the media attention toward Russian meddling/interference will wane; what this brief media analysis shows, however, is that the preoccupation with 'Russian meddling' is a distinct phenomenon which appeared in late 2016, largely in relation to the US presidential elections. There is scant indication of any continuity between the discourse around Russian meddling and the growing tension between Russia and the West that has become increasingly apparent, in particular after Russia's annexation of Crimea in 2014 (Trenin 2016); 'Russian meddling' as a media discourse is specifically linked to interference into domestic political processes in Western democracies and on both sides of the Atlantic has been heavily influenced by the framing established by US media. Before dissecting the main components of 'Russian meddling' and possible responses to them, the following section places them in the context of West-Russia relations.

\section{What is specifically Russian about Russian meddling?}

The fact that an external state actor may have successfully interfered in domestic political processes has come as a shock to the United States in 2016. On the contrary, concern with foreign meddling has been a major issue in Russia for a long time. The whole concept of 'sovereign democracy' formalised by Vladislav Surkov in 2006 and strongly associated with Vladimir Putin's tightening grip on power has been widely understood as a response to the preoccupation with Western interference in domestic politics in its 'near abroad' and in Russia itself (McFaul and Spector 2009). ${ }^{4}$

There is an established narrative in Russia according to which all activities associated with 'Russian meddling' were ultimately reactive or defensive in nature. After all, even the infamous article that gave the name to the non-existing 'Gerasimov doctrine' - a troubled expression often used as a shorthand for Russia's supposedly new hybrid war tactics - ultimately described what it perceived as the Western approach to interfering with domestic affairs in other countries (Galeotti 2019). By using and perfecting similar tactics, Russia would simply be updating its repertoire to include practices that the US had been using for a long time not only in Central or South America, but also in other regions, such as the Middle East, especially during the Arab Spring and, most importantly from the Kremlin's point of view, in Russia's 'near abroad' and in Russia itself. ${ }^{5}$

As Russia's neighbours know all too well, Russian interference in the domestic affairs of other countries did not start in 2016. Even the West's preoccupation with the specific tactics at the core of the post-2016 Russian meddling narrative is not new. In 2015, the EU launched its East StratCom Task Force known for its controversial "EU vs. Disinfo" project targeting Russian disinformation, well before Donald Trump's election in the United States. ${ }^{6}$ Yablokov (2015) published an academic article on conspiracy theories as a Russian public diplomacy tool: promoting controversial points of view to instil distrust in liberal elites was not a new idea for Russia in the fall of 2016. Politically motivated, large-scale cyberattacks 
had been used by Russia in its neighbourhood for a decade before they became a major issue in the US (Pernik 2018) and they continue to be a source of concern (UK Foreign Office 2020). ${ }^{7}$

\section{The vulnerabilities exposed by Russian meddling}

What is actually new about the post-2016 preoccupation with Russian meddling is a widespread realisation that modern technologies have brought newly shaped structural vulnerabilities to established Western democracies themselves. In one form or another, disinformation may be as old as humanity and it certainly had nefarious and even violent consequences at different point in times in history, but social media and the current model of the Internet have turned it into a fundamentally new challenge for liberal democracies. The increasing ubiquity of digital technologies in everyday life and communication has immensely increased the potential impact of cyberattacks even in comparison to only a few years ago. Indeed, even if Russia did exploit these vulnerabilities, there is little that ties them specifically to Russia.

As argued by Tufekci (2018), Russian meddling is only a symptom: "to heal, we need the correct diagnosis followed by action that treats the underlying diseases." In other words, rather then focus on Russia, it may be more sensible to take a more comprehensive approach that mitigates the vulnerabilities exposed by the scandals concerning Russian meddling. The Mueller investigation confirmed, providing abundant details, the existence of Russian attempts at interfering in the US 2016 presidential elections. Two operations were undertaken: a campaign of disinformation conducted through social media and a hacking-and-dumping operation against the Clinton campaign. The following sections will consider these two components and outline some of the responses that have been proposed in recent years to tackle these issues.

\section{Information operations, disinformation, and social media}

Given the sheer amount of resources poured into presidential campaigns in the United States, it is close to impossible that a (relatively speaking) tiny information operation run from the outskirts of St Petersburg in Russia had a substantial impact on the outcome of the vote. ${ }^{8}$ Yet, the way that social media facilitates the spread of polarising contents has been cause for concern well beyond that much debated operation. Indeed, if the object of that campaign was "to provoke and amplify political and social discord" (Mueller 2019: 4), it may have just contributed to what social media had already been doing for years (Neudert and Marchal 2019: 15). ${ }^{9}$ In this specific instance, disinformation may have been spread by Russian actors, but profit motives have proved to be powerful drivers, pushing both domestic and foreign actors to produce junk news on many other occasions (e.g. Burger et al. 2019; Bradshaw et al. 2019). More broadly, the current model of the Internet - averse to 
privacy and largely relying on unaccountable platforms - has come under increased scrutiny, in particular after new scandals such as that related to Cambridge Analytica and its mishandling of private data obtained through Facebook (Cadwalladr and Graham-Harrison 2018).

As appears from this brief overview, the concern with foreign meddling in time of elections quickly escalates to systemic consideration about the challenges to democratic societies coming from the increased digitalisation and privatisation of our public arena. The complexity of these issues, as well as the real risk that rushed regulation may cause more harm than good, should, however, not serve as an excuse for inaction. Indeed, researchers, working groups, and committees at various levels have worked to develop sensible policy proposals that mitigate these vulnerabilities. The devil may well be in the details, but at least on some aspects there is a broad consensus. For example, in many countries regulation on political campaigning has never been updated to include digital spaces, and, as a consequence, many of the transparency and accountability requirements that traditionally accompany elections do not currently stand online; well-meaning legislators should start from there, including comprehensive transparency obligations as well as limits on micro-targeting (Dobber, Fathaigh, and Borgesius 2019).

Comprehensive policy-oriented reports such as 'Protecting electoral integrity in the digital age' written by the Kofi Annan Commission on Elections and Democracy in the Digital Age (2020) serve as key points of reference and envisage sensible policies that would not only contribute to mitigate the risk of foreign interference, but also to foster an enabling environment for domestic democratic processes. Calls for stronger transparency requirements and considerable efforts to promote digital and media literacy are included, among other things, in official recommendations issued by the European Commission (2018), in reports for the European Parliament (Neudert and Marchal 2019), or in studies resulting from the work of parliamentary committees conducted at the national level (e.g. UK House of Commons 2019; Canada House of Commons 2018). Even when they refer to foreign interference or specifically to Russian meddling, all these reports argue in favour of structural responses, rather than focus on a specific external actor such as Russia.

\section{Hacking and dumping}

The second component of Russian meddling, as characterised by the Mueller report, is the hacking-and-dumping operation against the Clinton campaign. The coordinated efforts at maximising the visibility of the exfiltrated materials has fundamentally contributed to the impact of the operation, and it is no less important than the hacking operation itself. Readers who do not have a keen interest in cyber-security issues may well not even have heard that Chinese hackers violated the computer system of both the Obama and McCain campaign in 
2008 (Isikoff 2013) or that Russian hackers exfiltrated data from the computer networks of the German Parliament (Beuth et al. 2017): what is particularly new about the hacking of the US Democrats and the Clinton campaign in 2016 is, ultimately, its very notoriety.

Even when hackers do publish online the private communication of politicians they have illicitly obtained, the media reaction may be muted. For example, when more than $20 \mathrm{~GB}$ of emails from the servers of Lega, a prominent right-wing party in Italy, were hacked about a month before the Italian political elections of May 2018, the news barely featured in the media (Martelli 2018). Other scandals involving hacked personal communications of politicians in Europe did achieve some visibility in the media, but they had hardly any political impact (Soesanto 2017; Franceschi-Bicchierai, Koebler, and Maiberg 2019). Insisting that journalists fully consider the ethical implications of reporting on illicitly obtained materials may be relevant, but explicit regulations on this issue may be both useless (i.e. ineffective in the age of social media) and damaging (i.e. used to silence investigative journalists).

Also, in the case of cyber-security in time of elections there is a considerable consensus on viable policy options that should be pursued, as summarised for example in the relevant report by ENISA, the European Union cyber-security agency (ENISA 2019). The first basic concern in this context is to ensure high cybersecurity standards for the very infrastructure used to conduct elections. At its core, this is a technical and organisational issue to be approached through established best practices (NIS Cooperation Group 2018), enhanced cooperation between government agencies (van der Staak and Wolf 2019), and further exchange of experiences and information among partners (ENISA 2019: 11; Pope 2018).

A second specific vulnerability relates to the computer systems and the internal communication of political parties and campaigns. Although they are extremely high-value targets for both domestic and foreign actors, they do not seem to take their own cyber-security seriously enough. This is not necessarily by ill will: in comparison with corporate environments, decentralised organisations that involve volunteers may find it more difficult to enforce tight cyber-security practices. Even if they may eventually hold the keys to the state coffers and manage considerable resources, many political organisations operate on a shoe-string budget: having to decide between more electoral posters and expensive cybersecurity consultants, they have strong incentives to prefer the former. For that reason, ENISA (2019) argues in favour of the introduction of mandatory high cyber-security standards for political organisations and proposes to assist them throughout the adaptation process. Such initiatives are already taking place in various European country (Maurer and Brattberg 2018), and previous experience may well serve as a source of inspiration in other countries, keeping in consideration local needs and sensitivities. Guides for practitioners (Belfer Center for Science and International Affairs 2017) are useful tools and educating individuals is indeed an important element of a comprehensive cyber-security strategy, but 
political campaigners should not be left alone to fend off attacks from advanced, state-sponsored malicious actors. Assistance should come with the understanding that widespread default solutions, such as relying on foreign big tech companies, may be politically unacceptable. ${ }^{10}$

Finally, Russian meddling has once again highlighted the importance of defining a framework for reacting if a cyber-attack can be convincingly attributed to a foreign actor. ${ }^{11}$ The European Union has been working for a few years on its cyber-diplomacy toolbox which may become a useful point of reference in time of need (Moret and Pawlak 2017; Ivan 2019), and more dialogue along these lines is needed at the international level. Any such initiative should, however, include mechanisms that prevent quick escalation, also considering Russia's own aggressive use of cyber-operations in recent years (Greenberg 2019).

\section{Secret deals and illicit funding}

This chapter deliberately focussed on aspects that were directly related to the impact of new technologies on the information space due to their prominence in the Russian meddling narrative as epitomised by the Mueller report. However, perhaps the most hotly debated part of that investigation was aimed at determining - as it turned out, inconclusively - if the Trump campaign actively "conspired or coordinated with the Russian government in its election interference activities" (Mueller 2019; Bullough 2019).

In continental Europe, somewhat similar shenanigans involving Russia have revolved around actual or attempted transfers of money from Kremlin-related actors to friendly political forces. For instance, in 2014 Marine Le Pen's National Front obtained a loan for 9.4 million euro from a Prague-based, Kremlin-linked bank that had been used for unrelated money-laundering operations, in a deal that according to media reports was related to the Russia-friendly stance Le Pen took on Russia's annexation of Crimea (Gatehouse 2017). In what turned out to be an elaborate set-up, in July 2017 Austria's Freedom Party leader Heinz-Christian Strache was recorded on camera as he negotiated support from a woman he believed to be the niece of a Russian oligarch (Al-Serori et al. 2019). In July 2019, Buzzfeed News released secretly recorded audio of a meeting which took place in Moscow in October 2018, reported in a cover story published on the Italian weekly L'Espresso. During the meeting, three Russian and three Italian individuals were conspiring to use an oil deal to syphon off 65 million USD to be used to finance the political campaign of Lega (Tizian and Vergine 2019; Nardelli 2019). The issue of funds of dubious origins flooding political campaigns obtained particular prominence in the UK in recent years (e.g. Ramsay and Geoghegan 2017) and there may indeed be a Russian connection: a dedicated report by the UK Intelligence and Security Committee of Parliament is due to be published in 2020 (Bullough 2019).

Scandals related to specific individuals make for media-grabbing headlines, but do not lend themselves as easily to more generalisable patterns. Yet, even these 
stories shed some new light on contemporary vulnerabilities to Western democracies. In the case of the UK, its role as a comerstone for the global offshore industry makes it particularly vulnerable to the corrupting influence of 'dark money'; kleptocratic regimes in the post-Soviet space are a well-known source of such funds (Cooley and Heathershaw 2017; Bullough 2018a), but this is a global problem - an under-appreciated "dark side of globalisation" (Bullough 2018b) - rather than anything Russia-specific. Elsewhere, concerns about illicit funding may well serve as a reminder of the importance of transparency requirements for political campaigns and other actors such as foundations and thinktanks that in many countries are playing an increasing prominent role in domestic politics.

Fundamentally, the recent preoccupation with Russian meddling that emerged in late 2016 is not related to the cosy relationship between leading politicians and the Kremlin; For example, the explicit pro-Russian stance of leading figures such as former German Chancellor Gerhard Schröder or former Italian Prime Minister Silvio Berlusconi, as well as their flaunted friendship with Russian president Vladimir Putin have called for some criticism, but they have not been denounced as a case of Russian interference. There is also no sensible policy proposal that could (or should) deal with the personal preferences and political choices of politicians, as long as they remain within the boundaries of the law. There are, however, sensible policies that would reduce the risk that dark money interferes with domestic political processes.

More broadly, when thinking of policy responses to the concerns stemming from stories about 'Russian meddling', looking beyond the Kremlin is the safest approach for making democracies less vulnerable to foreign interference (from Russia or elsewhere) as well as more resilient to the challenges of domestic spoilers.

\section{Conclusion}

In recent years, Russian meddling has obtained extensive media attention and has led to increased pressure on policy makers and big tech companies to find ways to protect democracy from undue external interference. The preoccupation with foreign meddling is understandable, but it should also come with an appreciation of the fact that there is little of specifically foreign (or Russian) in the vulnerabilities that made Russian meddling possible, or at least plausible. Domestic spoilers motivated by politics or by profit - have used and will likely continue using some of the same techniques to a much greater extent.

Liberal democracies have no acceptable way to protect themselves from these kinds of operations without dealing with the newly shaped structural vulnerabilities that have come with the uptake of digital technologies. Fortunately, expert groups as well as national and international committees tasked to investigate these issues have put forward a number of meaningful policy proposals. At least on some of them, there is an extraordinary degree of consensus. Policy makers should know 
where to start and ensure that the preoccupation about these matters that emerged with Russian meddling isn't wasted.

Of course, Western governments would also do well to reason on a sensible course of action to manage the current confrontation with Russia (Trenin 2016). Countries bordering the Russian Federation should consider adequate measures to deal with Russia's much more pervasive presence in their information spaces while resisting the temptation of outright censorship even under extreme pressure (Mijatović 2014). These are, however, quite separate matters. When thinking of policy responses to Russian meddling into domestic political processes in Western countries, the better course of action is to focus on the vulnerabilities that make such interference possible.

\section{Notes}

1 This operationalisation of external - specifically Russian - meddling makes it possible to concentrate on a distinct subset of problematic instances of external interference. As a consequence, this chapter does not analyse other forms of external influence that are generally perceived as legitimate (e.g. transnational networks or regional cooperation mechanisms), nor others phenomena that, depending on the context, can be more problematic (e.g. different understandings of public diplomacy or democracy promotion).

2 These include the delayed release of an official dossier on Russian meddling in the UK and new revelations about Russian donors to the Tory party; other articles were related to the impeachment of Donald Trump in the United States.

3 The analysis of Spiegel and Repubblica was based on their online archives. For a debate on the usefulness of applying basic word frequency analysis to better define a case study, see Comai (2017).

4 Russia vividly denounced the West's active interference at the time of the "Orange Revolution" in Ukraine in 2004 (Ambrosio 2010). It should be acknowledged that external interference from both Russia and the West was perceived to be improper by large swathes of Ukrainian residents (Shulman and Bloom 2012).

5 To counter this narrative based on false equivalence, the Kofi Annan Commission on Elections and Democracy in the Digital Age (2020:87) argues in favour of establishing an international convention to "develop international norms that distinguish legitimate cross-border assistance from illicit or unlawful interventions."

6 On criticism of "EU vs. Disinfo", see for example Nijeboer (2018).

7 Given both the significant change of context and the distinct temporal hiatus between those phenomena and present events, the affinities between recent events and Soviettime practices with some contiguity with them are not discussed. An incomplete list of references would include disinformation activities (United States 1981; Martin 1982), "active measures" (Godson and Shultz 1985), as well as a specific attention to collect and use compromising materials (kompromat) on opponents.

8 For a debate on the meaning of 'information operation' and of alternative concepts, see in particular Wanless and Pamment (2019).

9 As pointed out by Neudert and Marchal (2019:15), the attention economy and the pressure to increase engagement on these platforms had already proved to be powerful incentives for "the dissemination of partisan and emotionally-charged content that reinforces tensions between users."

10 On top of a strong security record for all their users, big tech companies such as Google and Microsoft provide premium services with additional security to political campaigns for free, see Google's "Protect your election" (https://protectyourelection.withgoogle. com/), and Microsoft's "Defending democracy program" (https://m365forcampaigns. 
microsoft.com.). However, using services offered by US-based conglomerates with dubious records on matters such as so-called 'tax optimisation', abuse of monopoly power, and privacy, may be problematic for political campaigns.

11 On the issue of attribution of cyberattacks, see in particular Rid and Buchanan (2015).

\section{References}

Al-Serori, L., O. Das Gupta, P. Münch, F. Obermaier, B. Obermayer (2019) 'Caught in the trap', Süddentsche.De, 17 May 2019, https://projekte.sueddeutsche.de/artikel/politik/ caught-in-the-trap-e675751\%

Ambrosio, T. (2010) 'Russia', in: D. Ó Beacháin, A. Polese (eds), The Colour Revolutions in the Former Soviet Republics: Successes and Failures, London - New York: Routledge, $136-55$.

Belfer Center for Science and International Affairs (2017) 'Cybersecurity campaign playbook', Belfer Center for Science and International Affairs, November 2017, https:// www.belfercenter.org/CyberPlaybook.

Beuth, P., K. Biermann, M. Klingst, H. Stark (2017) 'Cyberattack on the Bundestag: Merkel and the Fancy Bear', Die Zeit, 12 May 2017, https://www.zeit.de/digital/2017-05/ cyberattack-bundestag-angela-merkel-fancy-bear-hacker-russia.

Bradshaw, S., P. N. Howard, B. Kollanyi, L.-M. Neudert (2020) 'Sourcing and automation of political news and information over social media in the United States, 2016-2018', Political Communication 37(2): 173-93.

Bullough, O. (2018a) Moneyland: Why Thieves \& Crooks Now Rule the World \& How to Take It Back, London: Profile Books.

Bullough, O. (2018b) 'The dark side of globalization', Joumal of Democracy 29(1): 25-38.

Bullough, O. (2019) 'The toxic relationship between Britain and Russia has to be exposed', The Guardian, 13 November 2019, www.theguardian.com/commentisfree/2019/nov/13/ relationship-britain-russia-money-report.

Burger, P., S. Kanhai, A. Pleijter, S. Verberne (2019) 'The Reach of Commercially Motivated Junk News on Facebook', edited by Sabrina Gaito, PLOS ONE 14(8): e0220446, available from: https://doi.org/10.1371/journal.pone.0220446.

Cadwalladr, C., E. Graham-Harrison (2018) 'Revealed: 50 Million Facebook profiles harvested for Cambridge Analytica in major data breach', The Guardian, 17 March 2018, www.theguardian.com/news/2018/mar/17/cambridge-analytica-facebook-influ ence-us-election.

Canada House of Commons (2018) 'Democracy under threat: Risks and solutions in the era of disinformation and data monopoly', Report of the Standing Committee on Access to Information, Privacy and Ethics, House of Commons,: www.ourcommons.ca/Content/ Committee/421/ETHI/Reports/RP10242267/ethirp17/ethirp17-e.pdf.

Cherto, M., A.F. Rasmussen (2019) 'The unhackable election - what it takes to defend democracy', Foreign Affairs, January/February: 156-64.

Comai, G. (2017) 'Quantitative analysis of web content in support of qualitative research. examples from the study of post-Soviet de facto states', Studies of Transition States and Societies 9(1), http://publications.tlu.ee/index.php/stss/article/view/346.

Cooley, A. A., J. Heathershaw (2017) Dictators Without Borders: Power and Money in Central Asia, New Haven, CT: Yale University Press.

Dobber, T., R. Ó. Fathaigh, F.J. Zuiderveen Borgesius (2019) 'The regulation of online political micro-targeting in Europe', Internet Policy Review 8(4), https://policyreview. info/articles/analysis/regulation-online-political-micro-targeting-europe. 
ENISA (2019) 'Election cybersecurity: Challenges and opportunities', Brussels: ENISA EU Cybersecurity Agency, www.enisa.europa.eu/publications/enisa-position-papersand-opinions/election-cybersecurity-challenges-and-opportunities.

European Commission (2018) 'Commission recommendation of 12.9.2018 on election cooperation networks, online transparency, protection against cybersecurity incidents and fighting disinformation campaigns in the context of elections to the European Parliament', C(2018) 5949 final. Brussels: European Commission, available from: https:// ec.europa.eu/commission/sites/beta-political/files/soteu2018-cybersecurity-electionsrecommendation-5949_en.pdf.

Franceschi-Bicchierai, L., J. Koebler, E. Maiberg (2019) 'Before Germany's massive hack, we learned what not to do with sensitive stolen information', Motherboard, 4 January 2019, https://motherboard.vice.com/en_us/article/xwji4a/germany-politicians-hack-andleak-what-not-to-do-with-sensitive-stolen-data.

Galeotti, M. (2019) 'The mythical "Gerasimov doctrine" and the language of threat', Critical Studies on Security 7(2): 157-61.

Gatehouse, G. (2017) 'Who's funding France's far right?', BBC News, 3 April 2017, available from: https://www.bbc.com/news/world-europe-39478066.

Godson, R., R. Shultz (1985) 'Soviet Active Measures: Distinctions and Definitions', Defense Analysis 1(2): 101-10.

Greenberg, A. (2019) Sandworm: A New Era of Cyberwar and the Hunt for the Kremlin's Most Dangerous Hackers, New York: Doubleday.

Isikoff, M. (2013) 'Chinese hacked Obama, McCain campaigns, took internal documents, officials say', NBC Investigations, 6 June 2013, http://investigations.nbcnews.com/_news/ 2013/06/06/18807056-chinese-hacked-obama-mccain-campaigns-took-internal-doc uments-officials-say.

Ivan, P. (2019) 'Responding to cyberattacks: Prospects for the EU Cyber Diplomacy Toolbox', Brussels: European Policy Center, https://www.epc.eu/en/publications/ Responding-to-cyberattacks-EU-Cyber-Diplomacy-Toolbox 218414.

Kofi Annan Commission on Elections and Democracy in the Digital Age (2020) 'Protecting electoral integrity in the digital age', www.kofiannanfoundation.org/app/uploads/ 2020/01/f035dd8e-kaf_kacedda_report_2019_web.pdf.

Martelli, F. (2018) 'Anonymous ha pubblicato online 70.000 email della Lega', Vice [online], 23 February, www.vice.com/it/article/evmqgn/anonymous-ha-pubblicato-online-70000email-della-lega.

Martin, L.J. (1982) 'Disinformation: An instrumentality in the propaganda arsenal', Political Communication 2(1): 47-64.

Maurer, T., E. Brattberg (2018) 'Russian election interference: Europe's counter to fake news and cyber attacks', Washington DC: Carnegie Endowment, https://carnegieen dowment.org/2018/05/23/russian-election-interference-europe-s-counter-to-fakenews-and-cyber-attacks-pub- 76435 .

McFaul, M., R.A. Spector (2009) 'External sources and consequences of Russia's "sovereign democracy",, in: P. Bumell, R. Youngs (eds), New Challenges to Democratization, New York: Routledge.

Mijatović, D. (2014) 'Communiqué by OSCE representative on freedom of the media on propaganda in times of conflict', OSCE Representative on Freedom of the Media, 15 April, available from: https://www.osce.org/fom/117701.

Moret, E., P. Pawlak (2017) 'The EU Cyber Diplomacy Toolbox: Towards a cyber sanctions regime?', Paris: European Union Institute for Security Studies (EUISS), www.iss. europa.eu/uploads/media/Brief_24_Cyber_sanctions.pdf. 
Mueller, R. S. (2019) 'Report on the investigation into Russian interference in the 2016 presidential election', Washington DC, www.justice.gov/storage/report.pdf.

Nardelli, A. (2019) 'Revealed: The explosive secret recording that shows how Russia tried to funnel millions to the "European Trump", BuzzFeed News, 10 July 2019, www. buzzfeednews.com/article/albertonardelli/salvini-russia-oil-deal-secret-recording.

Neudert, L.M., N. Marchal (2019) Polarisation and the Use of Technology in Political Campaigns and Communication, Brussels: European Parliamentary Research Service, www.europarl. europa.eu/RegData/etudes/STUD/2019/634414/EPRS_STU(2019)634414_EN.pdf.

Nijeboer, A. (2018) '[Opinion] Why the EU Must Close EUvsDisinfo', EUobserver, 28 March 2018, https://euobserver.com/opinion/141458.

NIS Cooperation Group (2018) 'Compendium on cyber security of election technology', CG Publication 03/2018, www.ria.ee/sites/default/files/content-editors/kuberturve/ cyber_security_of_election_technology.pdf.

Pernik, P. (2018) 'The early days of cyberattacks: The cases of Estonia, Georgia and Ukraine', in: N. Popescu, S. Secrieru (eds), Hacks, Leaks and Disruptions - Russian Cyber Strategies, Paris: European Union Institute for Security Studies, www.iss.europa.eu/ content/hacks-leaks-and-disruptions- $\% \mathrm{E} 2 \% 80 \% 93$-russian-cyber-strategies.

Pope, A. E. (2018) 'Cyber-securing our elections', Journal of Cyber Policy 3(1): 24-38.

Ramsay, A., P. Geoghegan (2017) 'The "dark money" that paid for Brexit', OpenDemocracy, 15 February 2017, www.opendemocracy.net/en/dark-money-investigations/you-aren-tallowed-to-know-who-paid-for-key-leave-campaign-adverts/.

Rid, T., B. Buchanan (2015), 'Attributing cyber attacks', Joumal of Strategic Studies 38(1-2): 4-37.

Shulman, S., S. Bloom (2012) 'The legitimacy of foreign intervention in elections: The Ukrainian response', Review of Intemational Studies 38(2): 445-71.

Soesanto, S. (2017) 'The Macron leak that wasn't', ECFR, 9 May 2017, www.ecfr.eu/ article/commentary_the_macron_leak_that_wasnt_7285.

Tizian, G., S. Vergine (2019) 'Quei 3 milioni russi per Matteo Salvini: ecco l'inchiesta che fa tremare la Lega', L'Espresso, 21 February 2019, http://espresso.repubblica.it/plus/ articoli/2019/02/21/news/tre-milioni-matteo-salvini-russia-1.331924.

Trenin, D. (2016) Should We Fear Russia?, Malden, MA: Polity Press.

Tufekci, Z. (2018) 'Russian meddling is a symptom, not the disease', The New York Times, 5 October 2018, www.nytimes.com/2018/10/03/opinion/midterms-facebook-foreignmeddling.html.

U.K. Foreign Office (2020) 'UK condemns Russia's GRU over Georgia cyber-attacks', Gov.Uk., 20 February 2020, www.gov.uk/government/news/uk-condemns-russias-gruover-georgia-cyber-attacks.

UK House of Commons (2019) 'Disinformation and "fake news": Final report', Eighth Report of Session 2017-19, London, UK: House of Commons, https://publications. parliament.uk/pa/cm201719/cmselect/cmcumeds/1791/1791.pdf.

United States (ed.) (1981) The Origins, Direction, and Support of Terrorism: Hearing Before the Subcommittee on Security and Terrorism of the Committee on the Judiciary, United States Senate, Vol. Serial no. J-97-17, Washington: US G.P.O., www.ncjrs.gov/pdffiles1/Digitization/ 82825NCJRS.pdf.

van der Staak, S., P. Wolf (2019) Cybersecurity in Elections: Models of Interagency Collaboration, International Institute for Democracy and Electoral Assistance, https://doi.org/10.31752/ idea.2019.23.

Wanless, A., J. Pamment (2019) 'How do you define a problem like influence?', Joumal of Information Warfare 18(3): 14.

Yablokov, I. (2015) 'Conspiracy theories as a Russian public diplomacy tool: The case of Russia Today (RT)', Politics 35(3-4): 301-15. 